\title{
Утраченное место в воспоминаниях о принудительном переселении и в социальных
} практиках

\author{
Ирина Коваль-Фучило
}

В воспоминаниях о принудительных переселениях типичным мотивом является описание места, которое пришлось покинуть не по своей воле. Это место в рассказах приобретает идеальные черты, образ утраченного рая. Идеализация чаще всего проявляется в описаниях красивых пейзажей, богатых природных ресурсов, успешного хозяйствования, особенно дружной сельской общины, а также в сознательном, а чаще неосознанном умолчании или уменьшении негативных воспоминаний, связанных с потерянным местом. Сегодня широко распространились различные формы социальной активности с целью мемориализации затопленных сел: ежегодные встречи переселенцев, издание книг о переселенных населенных пунктах, открытие памятных знаков вблизи водохранилищ.

Ключевые слова: устная история, воспоминания, миграция, затопленная территория, мотив „потерянный рай“, идеализация

20. век характеризируется многими принудительными миграциями. В украинской истории самыми многочисленными были вынужденные переселения из-за двух мировых войн, этнические чистки в результате так называемой операции „Висла“, выселение людей изза Чернобыльской аварии. Эти миграционные процессы давно стали предметом исследования (Грінченко та ін. (ред.) 2018; Гриценко та ін. 1996; Жванко 2009; 2012; Качмар 2019; Кузьменко 2010; 2018; Гук (ред.) 1997; Халюк 2013; Dyczok 2000; Prymaka-Oniszk 2017; Wylegała 2014). Среди менее известных переселений - предвоенные и послевоенные выселения людей из городов и сел в связи с их затоплением из-за строительства ГЭС. Антропологическое исследование принудительного переселения из зон затопления началось лишь в последнее 
десятилетие (Боса 2012; Горбовий 2015, 2018; Коваль-Фучило 2014а; 2014б; 2018; Скрипник (ред.) 2016; Godyń 2015).

25 марта 1954 года Совет Министров СССР принял решение о начале строительства Кременчугского гидроузла на Днепре. Сооружение ГЭС и водохранилища вызвало потребность перенести на новые места населенные пункты района. Сегодня об этих событиях помнит все меньше людей. 0 переселении в те времена было не принято говорить, а тем более писать. Главная тема публикаций и агитации 1954 года - строится новая ГЭС, новые города (сегодняшний Светловодск) и села, которые создадут специально для переселенцев, а это значит новые возможности с новыми мечтами (Сало, Стек 2012). Люди еще слишком хорошо помнили все репрессивные акты коммунистической партии, чтобы откровенно выступить против пересылки, да обещали им „лучшее будущее“, электрифицированные дома, помощь в строительстве нового жилья. Все же покидать свою землю никто не хотел, но пришлось это сделать и научиться жить на новом месте.

Сегодня в воспоминаниях об этих принудительных переселениях, как и в рассказах о других вынужденных миграциях, вызванных различными факторами, типичным мотивом является описание места, которое пришлось покинуть не по своей воле. Это место в рассказах приобретает идеальные черты, образ утраченного рая. Идеализация чаще всего проявляется в описаниях красивых пейзажей, богатых природных ресурсов, успешного хозяйствования, особенно дружной сельской общины, а также в сознательном, а чаще неосознанном умолчании или уменьшении негативных воспоминаний, связанных с потерянным местом.

Переселенцы из зон затопления с горечью описывают утраченные пейзажи и угодья:

Там у нас был очень хороший огород. Там у нас было клубники много, огород большой, сенокос для коровы был свой. И кой-какое было деревце: то сливы, то груши. Такое было. Тогда много у нас садов там не было, где посадки взять, чтоб его посадить. А так все очень хорошо родило. Был и низ, был и бугор там. Все мы свое выращивали, и были довольны, потому что там все было (ЧЕА);

Очень хорошая земля, всё родило, и сады имели, и... ну, было: и картошка родила, и свекла (ЧЕА).

Такие же тенденции прослеживаются в рассказах украинских переселенцев операции „Висла“, когда достаточно часто именно идеализированными описаниями родной деревни начинают воспоминания. Респонденты отмечают урожайность своих земель, отмечают, 
что поля всегда были вовремя обработаны. „От востока села были общественные пастбища и сенокосы, с запада плодородные поля“ (Гук (ред.) 1997: 292); „Ой это Загуменье! Какие же это были поля! (...) сами только цвета и ароматы“ (Гук (ред.) 1997: 128).

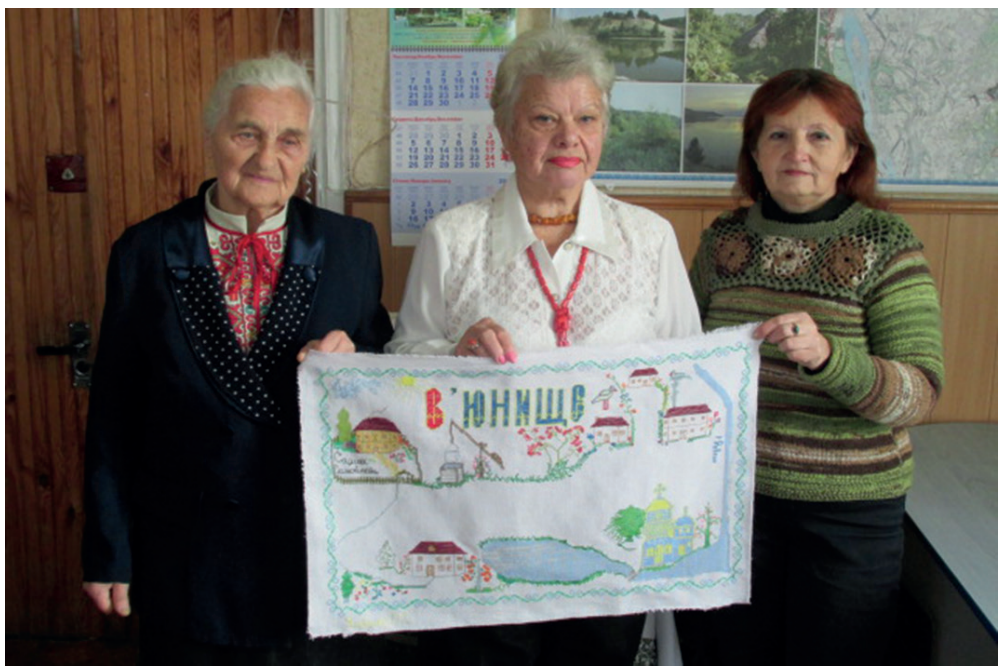

Сл. 1. Вышивальщицы Нина Лазенко, Ольга Яковенко и Алла Литкова с элементом рушника-памяти (село Вьюнище, укр. В'юнище)

Часто в воспоминаниях наши рассказчики дают обобщенную положительную оценку своему хозяйству, которое они вынуждены были разобрать, фактически уничтожить, и перенести на новое место: „Как там люди жили хорошо, а море, поставили море“ (ГМИ); „А я как подумаю, что мы так жили хорошо - и убираться, Боже!“ (ВАП).

В воспоминаниях чаще всего идеализируют: 1. естественное местоположение села; 2. собственное приусадебное хозяйство; 3. сельскую общину.

1. Природные пейзажи утраченного села всегда очень живописные и часто выигрывают по сравнению с вынужденным местом поселения: „Там у нас хорошо было на хуторке тоже: гора, а внизу лес был ольховый, зелено было тоже, сады были у всех“ (ОЕП); „А там у нас хорошо было: гора, здесь и лес снизу“ (ОЕП); „А там такое оно: деревья, тепло, травы. Очень красиво было. Многим оно так снится (...) К воде, вниз, к лужайки хочется. И хотя здесь такая земля, такой чернозем, а воды нет" (ЗВФ). Лучшей на родном месте была не только земля, а вода и даже воздух: „Мне 62 или сколько, мне там лучше было, как вот тут. Там оно просто было, понимаете, ну как вам сказать, - луг там. И как мне и воздух не такой“ (ЮНС). 
Закономерно, что люди, которые много веков жили у реки, самой большой проблемой на новом месте считают отсутствие живой, постоянной воды:

Переселили - все. Ну, это вот хорошо, что я вот на низу. Вот вы на гору пойдете в селе - то там же невозможно! Воды вообще никогда нет! Пусть, я говорю, летом - огороды поливать, зимой нет напиться. Нету напиться - таблетки запить! Да, конешно! Переселили людей - как хотите, так и живите. Ну надо же хоть какими-то мозгами думать. И там вообще! На счоты воды - это же грех людям не давать воды (ЮНС).

Переселенцев удивляет, как их нынешним односельчанам удавалось организовывать свой быт без постоянной близости природного водоема:

А что же! И там же лучше было, потому что Днестр близко. Пряли, все. (...) Меня не подтапливало, я под горой. У меня речушка текла. Пошла ноги помыла, всьо что надо помыла, постирала - и все! Тянет туда. Привычка на место, и тянет туда. Я немного жила, и то меня тянет туда (ТOC).

Привозная, не естественная вода никогда не заменит постоянной, живой: „Вот моя сестра в Черкассах, и то, говорит, покупает воду. И есть в кранике, так она же не годится. Она то хлоркой, то с чем там. Они хлорируют. Негодная пить“ (ЮНС); „Так вот те старые говорят: 'Это мне не вода, шо будет бежать по трубе'. Вода должна быть там, где источник есть. Потому как всякие времена бывают“ (БВИ).

Усилению идеализации способствует использование бинарной оппозиции, на полюсах которой расположены две локации - потерянное село и вынужденное место поселения. Часто такая конструкция это поэтическая картина утерянного пейзажа в противовес участку, который люди получили на месте поселения: „Ну, мне там лучше было. Я там привыкла. Хорошо там было. А тута шо? Видите, нет нигде ничего“ (ЮНС); „Мне выпала еще одна неродная - канадская земля, на которой не куют в лесу кукушки, не поют жаворонки, не слышно соловьев. И нет здесь ни вишневых садов, ни ласточек, ни аистов, ни всего, что называем родным“ (Гук (ред.) 1997: 118).

Важно отметить, что типичной чертой описания утраченного села есть многочисленные микротопонимы: „Мы знаем каждый овражок, где это были дома наши: Прокопов ярок, Жидовский ярок, Рипа, там мостик был, и то Згониво - там скот сгоняли. Панский ярок - здесь близко в селе“ (ЛФЛ); „Перед войной Корни делились на такие кутки: Кут, Ставыще, Майдан, Старина, Подречье, Заречье, Выгон, Садок и 
поселок Вербовые“ (Гук (ред.) 1997: 292). Такое разнообразие номинации ни разу не встречается в описании новых поселений, в этих описаниях почти нет микротопонимов. В противоположность - имеем здесь номинации с семантикой необжитости, неупорядоченности: „огромное ничье поле“, „мы еще не имели выделеной земли“.

Для усиления статуса правильности и правдивости своего рассказа о потерянном рае информанты приводят высказывания третьих лиц о затопленном селе:

Да, приезжают, и приезжают, и приезжают. (...) Из Канады приехали, да говорит, тут на горе возле креста. Так посмотрел в одну сторону, в другую сторону, кругом посмотрел да и говорит: „Вот тебе Канары, это тебе... Лучшего и нет места. Мы мир объехали, но такой красоты не нашли“ (ЛПА).

Типичный мотив воспоминаний переселенных лиц - описание локации, на которой расположен их дом. Это место описывают как значительно лучшее по сравнению с выделенным для переселения участком:

Ну, такая красивая хата, очень хорошо построена, потому что мы под самой горой жили, и она очень у нас на таком веселом месте, на все село очень видно ее. И уже очень хорошие окна сделали, большие, потому что это маленькие были в старом доме. Очень насадила вазонов, расцвили - на все село! Кто идет, говорит: „Ну в этой женщины цветов!“ Очень росли. Полные окна цветов, такие-вот большие цветы кругом! Я как припомню - так мне жалко. Как пришла в этот дом, а в нем - Боже, Боже - холодно! (ЛПА).

Такие описания являются loci communes в воспоминаниях людей, которые построили новые дома в период после Второй мировой войны и перед затоплением: „Такие дворы построили, такая хата огромная! Под плиточкой, а и все цементом. Такие дома построили, кухни!“ (ВАП).

2. Для каждой сельской семьи жизненно важно собственное поле, своя земля, сад. В воспоминаниях переселенных лиц утраченные поля, земля, огороды всегда лучше, урожайнее по сравнению с выделенным для обработки участком: „У нас там был хороший огород“ (ЮНС); „Дом был новый, город был хорош. Нам очень хорошо в Бакоте жить. Там так как яма. Там ни ветров никогда не было, ничего. Там очень хорошо“ (ГНИ); „Там был красивый сад. Запомнилось, который виноград там был. Здесь тоже есть сад у меня посажен, но это не те сады, что там были. То уже погубили. Теперь стараются восстановить 
такие сливки, груши“ (ГНИ). Именно в описаниях пейзажей, приусадебного хозяйства, которые люди вынуждены были потерять, прочитывается мотив утраченного рая. Для усиления образа потерянного рая в воспоминаниях идеализированные описания предшествуют или соседствуют сценам его разрушения, высказыванию особой горечи от потери, нежелания переселяться:

Вот представьте себе. У нас такие люди там жили, были хорошие сады. Ему говорят: надо убирать. А ему жалко пылять ту яблоню или грушу. И вдруг сад зацвел - цветет, а ему говорят: убрать! И приезжает бульдозер, и начинает те деревья викорчевывать! И он снимается с этого участка и уходит. Какое у него впечетление на душе?! Чтоб он всю жизнь его делал, сажал, а они приехали - им всьо равно, им надо „освободить под затопление“" (БВИ);

Все время снится, что я там. Мне и сейчас снится, что я там. Там же золотая земля. Боже! Там жизнь была, что я даже не могу сказать! Лучше, чтобы я там была скончалась! (КГИ);

Боже, это... так люди не хотели уходить, так плакали, у кого очень хорошее хозяйство, дом новый, кухня новая, сарай здоровый, всё, за домом сад - такое дерево плодоносит! (ВАП).

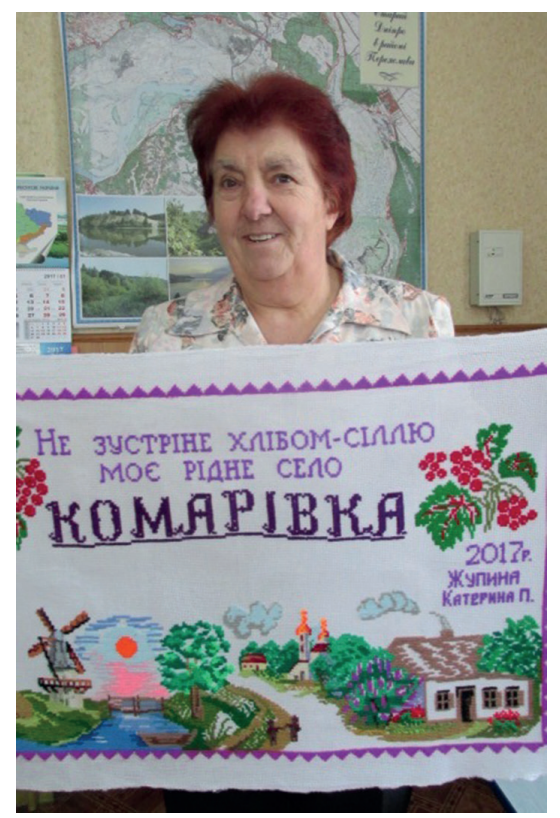

Сл. 2. Элемент рушника „Комаровка“ вышила Екатерина Жупина (село Комаровка, укр. Комарівка) 
3. Лучшими на потеряном месте были не только природа и угодья, а также сельская община:

И село было очень дружное. (...) А тогда, когда уже это так современные более, то начали: кто-то приезжий, кто проездом, кто-то приехал. Кто поселился, то увидел, что очень красивое село, дома были колхозные, колхоз начал строить (...) и начали съезжаться. И армяне приезжали, и русские, потому что видели, что красивое село. Колесо осмотра - как в городе, дома четырехэтажные были. Они и сейчас есть, которые живут в квартирах. Тогда уже немножко люди недружные стали. А именно в [19]50х годах. Как еще не было переселения, то люди дружны были, друг другу помогали (ЗВФ);

Нам то хорошо на низу жить. Село маленькое, очень дружеские люди, никаких, никакого ничего у нас там не было (ЛФЛ);

А такая Бакота была, что нет на всем побережье такого села. Очень дружное и очень красивое село (ЛПА);

Это такая была община, это такие были любезные люди, что если строить дом - то все, если свадьбу гуляють - то все. Сегодня в вас свадьба, то вся, чисто вся Бакота у вас. Чисто - до одного дома, все! (ЛПА).

Для подтверждения этой позиции переселенцы не устают рассказывать сцены прощания с односельчанами, которые в силу разных причин были вынуждены иметь новый дом далеко от компактного поселения людей своего села:

Всех мы провожали. Те ехали в Одессу, а те - в другое село, а те туда, а мы вот на месте были, мы никуда не переселились. Боже, идем провожать, берем рушники, берем хлеб на руншике - все! Випровожаем, как родную маму или брата. (...) Отдавали хлеб тем людям с рушником, благословили их, чтобы им было хорошо там. А как можно разойтись? К полудню плачем все, и никак не могут они на машину сесть и поехать. Машина стоит полная, нагружено всего из дома, а машина не едет, потому что не можем сдвинуть никак, не можем разойтись - обнимаемся и плачем, обнимаемся и плачем (ЛПА).

Своеобразной, так сказать, косвенной формой идеализации утраченного рая является постоянное декларирование готовности переселиться обратно на затопленное пространство, как только с него спустят воду. То есть потерянное место было настолько хорошим, что даже после продолжительной жизни на новых поселениях люди гото- 
вы к возвращению. Этим loci communes в воспоминаниях практически всегда предшествует идиоматическая фраза если бы воду спустили:

Вот и ещё говорят: а чтоб спустили воду - мы бы поехали туда. Там виноградники были такие, всьо (НАГ);

Трагедия была, конешно, очень, очень трагедия была. Говорят: вот, если бы воду спустили - мы бы возвращались обратно. Там были сады, там у нас было очень красиво! Пастбища были, все. Они здесь живут, а где птичка родилась - там ее и тянет. Есть такие, которые говорят: „Если бы воду спустили, мы бы и сегодня вернулись назад“ (ГМИ).

Идея восстановления, возрождения села является ведущей в воспоминаниях переселенцев, которых отселили из их родных мест, но территория села не была затоплена, поскольку из-за ошибки в расчетах или по другим причинам вода не покрыла эти земли: „Село находится на высоком холме, к которому водохранилище не добралось. Все переселенцы мечтают вернуться на земли древней Боровицы. Говорят, как только спустят воды морей, то готовы водрами носить ил из Днепра, чтобы его очистить“ (Кузьменко-Лісовенко 2018: 215).

Идеализация потерянного места приобретает не только вербальные формы - она также реализуется в различных социальных практиках, которые активизировались в последнее время. Имеются ввиду: ежегодные встречи переселенцев затопленных сел, которые происходят в различных регионах; любительское и профессиональное издание книг о переселенных селах; официальные формы мемориализации памяти о затопленных селах (установка памятных знаков вблизи бывших поселений, сбор экспонатов для будущего музея выселенных сел и т.д.).

Первая встреча жителей затопленных сел на Переяславщине состоялась в 2005 году в Музее народной архитектуры и быта Среднего Приднепровья, ныне - Национальный историко-этнографический заповедник „Переяслав“ (НИЭЗ). С тех пор такие мероприятия получили распространение, продолжаются до настоящего времени и происходят чаще всего летом. В Переяславе проживают переселенцы нескольких ближних затопленных сел (Цибли, Вьюнище, Козинцы, Комаровка, Городище). Каждое село имеет свою дату встречи, приуроченную, как правило, ко дню праздника села, то есть на храмовый праздник. Мероприятия эти „всегда проходят в атмосфере радости общения, там звучат песни, декламируются новые стихи“ (Іващенко 2018). Сегодня рассказы о таких встречах стали типичным мотивом в воспоминаниях о переселении: 
Пару лет назад было 30 лет, как переселение было. То в долине сами люди собрались, приглашали тех людей, которые были по другим селам. И они приезжали сюда. А с Бакоты человек, уже он живет в Хмельницком, - он директор оркестра. И оттуда привез своих музыкантов. Наши люди собрались, варили уху, угощали этих людей. То там было так много людей, очень много! Здесь Тарас (Горбняк), так как он уже на работе, приглашения, ну, пригласительние открытки послал, и те люди из других сел приехали сюда. Так им и музыка играла, и столы хорошие такие. После этого, уже после угощения, я была тогда тоже, после стола приплыл этот корабль, большой такой. И там женщины одели рубашки вышитые, сели на этот корабль, и он сделал круг. Набрали цветов много и бросали те цветы так, где кто жил. Пели песни (ДТА).

Похожие почитания затопленных сел состоялись и в других регионах Украины. Эти события часто происходят при участии священников, которые отправляют панихиды по умершим жителями затопленных сел, освящают мемориальные доски, часовни, кресты (Кузьменко-Лісовенко 2018: 172, 174, 175). Присутствие духовных лиц предоставляет празднику особую важность и значение, повышает его социальный статус.

Обязательными составляющими на встречах переселенцев является совместное застолье, исполнение песен, воспоминания о затопленном селе, фотографирование. В воспоминаниях подчеркивается взаимная приветливость между бывшими односельчанами: „Мы с радостью здороваемся, дружно обнимаемся, потому что односельчане - это как родственники“ (Кузьменко-Лісовенко 2018: 153). В опубликованных письменных воспоминаниях описания этих собраний ощутимо идеализированные и романтизированные, характеризуются возвышенной риторикой:

У нашего славного озера Казар организовали обед на разостланных рушниках прямо на земле. Традиционная уха из рыбы и много других блюд. Желающие катались на моторной лодке по озеру, доставали замечательные лилии, которые будто нарочно ждали нас. Пожалуй, озеро тоже соскучилось по родным людям и в знак благодарности, что мы приехали проведать его, подарило нам прекрасные цветы (Кузьменко-Лісовенко 2018: 152-153).

Среди других ритуализованных форм общественной активности с декларируемой целью „объединить усилия неравнодушных граждан и переселенцев из затопленных днепровскими водохранилища- 
ми территорий для воспроизведения и сохранения памяти о затопленной земле, о людях и их семьях“ - создание вышитого рушника, так называемого „рушника-памяти о затопленных селах“ (Іващенко 2018). Он будет состоять из нескольких прямоугольных частей. Каждый такой прямоугольник посвящен одному выселенному селу.

Сейчас уже активно создают отдельные его [рушника] части, которые к празднику города [Переяслава] будут сшиты в одно полото (...) Наши известные вышивальщицы под руководством Нины Лазенко выступили инициаторами вышивания рушникапамяти о затопленных селах и сейчас уже активно создают отдельные его части, которые будут вместе сшиты. Лучшее место для этого рушника, конечно же, в новом музее (Іващенко 2018).

Еще одна новая оригинальная социальная активность - ежегодные соревнования под названием Заплыв 'Днепр ревучий'. Участники заплыва должны преодолеть трехкилометровое расстояние между двумя берегами Каневского водохранилища свободным плаванием. Впервые такое событие произошло 30 июля 2016 года. В 2019 году состоялся четвертый такой заплыв. „Пловцы из Переяславщины, Киева, Кропивницкого, Кременчуга, Обухова и Борисполя преодолели дистанции 10 и 3,7 км с правого берега на левый (с Трахтемирова и от Батуриной горы - до береговой черты Переяславщины)“ (Іващенко 2019). Организаторы так декларируют суть и цель мероприятия: Днепр ревучий - это спортивно-культурное просветительское мероприятие, которое ежегодно организуется с такой целью: сохранение памяти об уникальных затопленных местах Переяславщины; популяризация активного и здорового образа жизни; сохранение украинской истории и культуры; формирование патриотичного и экологического сознания; развитие туристического потенциала; содействие развитию творческих инициатив молодежи (Іващенко 2019).

Сегодня главная, но не единственная цель переяславских активистов - создание музея истории Старого Днепра и затопленных сел. Члены общественной организации Старый Днепр декларируют ряд своих основных задач:

Планируется открытие специального историко-краеведческого музея, информационного центра с патриотическими объектами Киевщины, создание смотровой площадки на затопленные села (куда в этом году [2019] уже приезжало в рамках патриотично-просветительских и туристических мероприятий более 1000 детей и взрослых), установление памьятника затопленным селам, публикация тематических книг и т.д. (Іващенко 2019). 


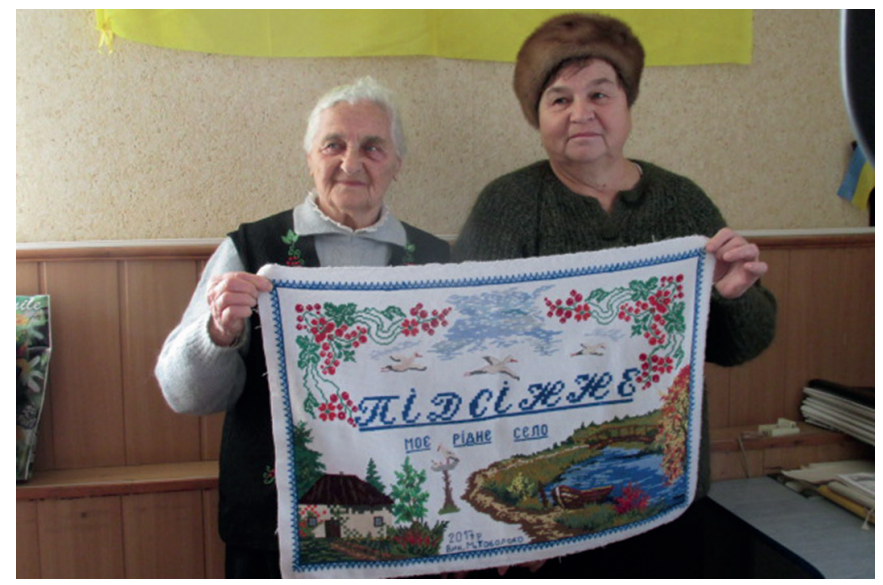

Сл. 3. Мария Тоболько (справа) - автор элемента рушника „Подсенное“ (село Подсенное, укр. Підсінне)

Последние годы характеризуются активизацией издательской деятельности, посвященной истории затопленных сел. Так, в 2007 году вышла книга Михаила Лесика Цибли - мое родное село на Переяславщине, которая сегодня является библиографической редкостью. Позже, в 2015 году, был издан историко-краеведческий очерк Софии Сороковой Не летят ласточки в Зарубинцы (Сорокова 2015). В аннотации к книге говорится:

В Переяслав-Хмельницком районе Киевской области в результате создания Каневского водохранилища (середина 1970х годов) было уничтожено более десяти сельских населенных пунктов. Их жители переселились с обжитых мест и навсегда потеряли свою малую родину. Одним из таких сел на правом берегу Днепра было село Зарубинцы. Эта книга является попыткой сохранить память о прошлом родной земли, рассказать о жизни зарубинецкой общины и привлечь внимание современников к проблемам исторического, культурного и духовного наследия нашего края.

В 2018 году положено начало серии Затопленные села Переяславщины. Первой книгой серии является издание Затопленный рай: Андруши в воспоминаниях и документах (автор-составитель - журналист-краевед Николай Михняк) (Михняк (упоряд.) 2018). Аннотация к книге содержит следующую информацию:

О[бщественная] О[рганизация] 'Старый Днепр' предлагает под названием 'Затопленный рай: Андруши в воспоминаниях и документах' первое издание серии 'Затопленные села Переяс- 
лавщины', подготовленное в рамках научно-просветительского проекта по обнародованию материалов о затопленных Каневским водохранилищем селах и их жителях. В книге собраны и представлены вниманию читателей воспоминания и документы о селе Андруши и его жителях с 20-х годов XX века до 1970 года, года массового переселения в Новые Андруши (микрорайон г. Переяслав-Хмельницкий). Речь идет о жизни андрушан в ужасные времена коллективизации, голодоморов 1921-1923 и 1932-1933 годов и голодовку 1947 года, о Второй мировой войне и принудительном выселении из родной земли, затопленной водами Каневского водохранилища (Михняк (упоряд.) 2018: 2).

Интересно, что это не первое издание о селе Андруши, - этой книге предшествовала краеведческая студия украинского писателя, этнографа Дмитрия Косарика (1904-1992), которая сохранилась в отделе Архивных научных фондов рукописей и фонозаписей Института искусствоведения, фольклористики и этнологии им. М. Т. Рыльского НАН Украины. В 2016 году этот материал был подготовлен к печати (Скрипник (ред.) 2016).

Нам Подсенное теперь только снится... - второе издание серии, „подготовленное в рамках научно-просветительского проекта по обнародованию материалов о затопленных Каневским водохранилищем села“ (Михняк, Зубер 2019). Авторами-составителями издания является, как и в предыдущей книге, журналист-краевед Николай Михняк и научный сотрудник НИЭЗ „Переяслав“ Светлана Зубер.

Независимо от переяславской организации в 2018 году в Киеве была издана книга Екатерины Кузьменко-Лисовенко Затопленная Приднепровская цивилизация. История. Человеческие судьбы (Кузьменко-Лісовенко 2018). Это литературно отредактированы воспоминания переселенцев, опубликованные с фотографиями из частных семейных альбомов жителей затопленных сел.

В современных воспоминаниях о переселении из зон затопления, как и в воспоминаниях других вынужденных мигрантов, повторяющимся является мотив потерянного рая, который вербализируется в типичных идеализированных описаниях своего родного села. С такой тенденцией связаны также невербальные формы особого почитания затопленных сел, например, ежегодные встречи бывших односельчан, сбор и публикация материалов (воспоминаний, фотографий, документов) о затопленных селах, установление мемориальных плит. Можно предположить, что такие общественные инициативы обусловлены и потребностью людей видеть своих бывших земляков, и тем, что у людей появилась финансовая возможность реализовать эту потребность. 


\section{Библиография}

Боса, Любов (2012). Зміни ландшафту Подніпров'я у XX столітті як соціокультурна проблема. Народна творчість та етнологія 4, 53-64.

Грінченко, Гелінада, В. Науменко, С. Телуха (ред.) (2018). Вільча - переселене село. Харків: Друкарня Мадрид.

Горбовий, Олександр (2015). Проблема Дніпрових порогів та Дніпрогес (19271932 рр.): стратегія адаптації. Наукові записки з української історії 37, 95102.

Горбовий, Олександр (2018). Затоплене Придніпров'я: місця пам'яті та музейні експозиції (XX - початок XXI ст.). ПЕРЕЯСЛАВІКА: Наукові записки Національного історико-етнографічного заповідника 'Переяслав' 14 (16), 322-331.

Гук, Богдан (ред.) (1997). Пропам'ятна Книга. Варшава: Тирса.

Жванко, Любов (2009). Біженство Першої світової війни в Україні. Документи і матеріали. Харків: ХНАМГ.

Жванко, Любов (2012). Біженці Першої світової війни: український вимір (1914-1918 рр.). Харків: Апостроф.

Іващенко, Віталій (2018). Зберегти пам'ять про затоплені села. http://olddnieper. org.uа, дата звернення 29. 02. 2020.

Іващенко, Віталій (2019). Заплив 'Дніпро ревучий - 2019'. http://olddnieperorg. uа, дата звернення 29. 02. 2020.

Качмар, Марія (2019). Народні оповідання про переселення українців з Закерзоння у 1940-х роках: фольклорна та історична пам'ять (на матеріалах села Тулиголови Городоцького району Львівської області). Народознавчі зошити 4, 915-927.

Коваль-Фучило, Ірина (2014а). Рассказы переселенцев из зоны затопления Кременчугским водохранилищем. Живая старина 3, 38-40.

Коваль-Фучило, Ірина (2014б). Осмислення примусового переселення із зони затоплення Дністровським водосховищем (за матеріалами усноісторичних наративів). Слов'янський світ 13, 215-231.

Коваль-Фучило, Ірина (2018). Концепт „земля“ в оповідях про примусове переселення. Lemkovia, Bojkovia, Rusíni - dejiny, súčasnost', materiálna a duchovná kultúra VII/2. Banská Bystrica: Vydavatel'stvo Univerzity Mateja Bela v Banskej Bystrici, Belianum, 25-40.

Кузьменко, Оксана (2018). Драматичне буття людини в українському фольклорі: концептуальні форми вираження (період Першої та Другої світових воєн): монографія. Львів.

Кузьменко, Оксана (2010). Концепт „батьківщина“ в парадигмі часопросторових образів у фольклорних новотворах про виселення. Література. Фольклор. Проблеми поетики 34, 210-219.

Кузьменко-Лісовенко, Катерина (2018). Затоплена Придніпровська цивілізація. Історія. Людські долі. Київ: [б. в.].

Михняк, Микола (упоряд.) (2018). Затоплений рай: Андруші у спогадах та документах. Київ: Український пріоритет.

Михняк, Микола, Світлана Зубер (2019). Нам підсінне тепер тільки сниться. Київ: Український пріоритет. 
Сало Ірина, Левко Стек (2012). Затоплена Україна. 25 міст і сіл під водами Дніпра - так вирішила партія. Українська правда, http://www.istpravda.com.ua/ articles/2012/03/18/73460/, дата звернення 3. 3. 2020.

Скрипник, Ганна (ред.) (2016). Село Андруші на Переяславщині. Історико-етнографічний нарис. Київ: Видавництво ІМФЕ.

Сорокова, София (2015). Не летять ластівки у Зарубинці: історико-краєзнавчий нарис. Переяслав-Хмельницький: Лукашевич О. М.

Халюк, Леся (2013). Усні народні оповідання українців-переселенців Лемківщини, Холмщини, Підляшшя та Надсяння: жанрово-тематична специфіка, художні особливості. Київ: Інститут мистецтвознавства, фольклористики та етнології ім. М. Т. Рильського.

Bartmiński, Jerzy (2018). Home - a universal and culture-specific concept. The axiological lexicon of Slavs and their neighbours. The Concept of Home. Vol 1. Ed. Jerzy Bartmiński. Lublin: Maria Curie-Skłodowska University Press, 16-41.

Dyczok, Marta (2000). The Grand Alliance and Ukrainian Refugees. Oxford: St. Martin's Press.

Godyń, Maria (2015). Opowieść o utraconej wsi Maniowy. Studium z antropologii pamięci. Kraków: Polska Akademia Umiejętności.

Prymaka-Oniszk, Aneta (2017). Bieżeństwo 1915. Zapomniani uchodźcy. Wołowiec: Czarne.

Wylegała, Anna (2014). Prszesiedlenia a pamięć. Studium (nie)pamięci społecznej na prszykładzie ukraińskiej Galicji i polskich 'Ziem odzyskanych'. Toruń: Wydawnictwo Naukowe Uniwersytetu Mikołaja Kopernika.

\section{Записи сделаны от переселенцев из таких затопленных сел:}

Бакота Камянец-Подольского р-на Хмельницкой обл.

Жовнино Градизкого р-на Полтавской обл.

Калабарок Новоегоровского р-на Кировоградской обл.

Кониловка Камянец-Подольского р-на Хмельницкой обл.

Кривчани Камянец-Подольского р-на Хмельницкой обл.

Морозовка Глобинского р-нп Полтавской обл.

Надднестрянка Камянец-Подольского р-на Хмельницкой обл.

Новоселовка Кременчукского р-на Полтавской обл.

Скородистик, частично затопленное, бывший Ирклеевский р-н Полтавской обл., сегодня Черкасская обл.

\section{Информанты}

БВИ - Бугаенко Василий Иванович, 1941 г.р., переселенец, род. в с. Пеньковка Запись в с. Подгорное Кременчукского р-на Полтавской обл. 20. 05. 2012.

ВАП - Василишина Анна Петровна, 1927 г.р., переселенка, род. в с. Бакота, Запись в с. Гораивка Камянец-Подольского р-на Хмельницкой обл. 18. 07. 2014. 
ГНИ - Горбняк (Фарфанюк) Надежда Ивановна, 1934 г.р., род. в с. Бакота. Запись в с. Гораивка Камянец-Подольского р-на Хмельницкой обл. 19. 07. 2014.

ГМИ - Гречка Мария Ивановна, 1927 г.р., род. в с. Новоселовка Кременчукского р-на Полтавской обл. Запись в с. Новоселовка 19. 05. 2012.

ДТА - Дубенюк Тетяна Александрівна, 1957 г.р., переселенка, род. в с. Бакота. Запись в с. Гораивка Камянец-Подольского р-на Хмельницкой обл. 21. 07. 2014.

ЗВФ - Загреба Валентина Федоровна, 1950 г. р., род.в с. Скородистик. Запись в с. Скородистик 01. 08. 2014.

КГИ - Кособуцкая Галина Ивановна, 1939 г. р., род. в с. Теремцы, жительница

с. Бакота. Запись в с. Гораивка Камянец-Подольского р-на Хмельницкой обл. 19. 07. 2014.

ЛПА - Левченко Параска Алексеевна, 1940 г. р., переселенка, род. в с. Кривчаны, в Бакоту пошла невесткой. Запись в с. Гораивка Камянец-Подольского р-на Хмельницкой обл. 19. 07. 2014.

ЛФЛ - Литвинюк Федора Лаврентиивна, 1942 г. р., род. в с. Надднестрянка. Запись в с. Гораивка Камянец-Подольского р-на Хмельницкой обл. 18. 07. 2014.

НАГ - Никуляк Александр Григорович, 1926 г. р., переселенец, род. в с. Кониловка, бухгалтер. Запись в с. Гораивка Камянец-Подольского р-на Хмельницкой обл. 18. 07. 2014.

ОЕП - Онищенко Евдокия Петровна, 1928 г. р., переселенка, род. в с. Скородистик. Запись в с. Скородистик 01. 08. 2014.

TOC - Трофимчук Ольга Семеновна, 1949 г. р., род. в с. Кониловка. Запись в с. Гораивка Камянец-Подольского р-на Хмельницкой обл. 21. 07. 2014.

ЧЕА - Чепинога Екатерина Андреевна, 1931 г. р., род. в с. Скородистик. Запись в с. Скородистик 19. 08. 2014.

ЮНС - Юхно Нина Семеновна, 1952 г. р., переселенка, род. в с. Скородистик. Запись в с. Скородистик, 01. 08. 2014.

\section{Источники иллюстрации}

Все фото взяты с сайта 00 „Старый Днепр“, http://olddnieper.org.ua.

\section{Lost Place in Memories about Forced Resettlement and in Social Practices}

Iryna Koval-Fuchylo

\section{Summary}

In the memories about forced resettlement caused by various factors, a typical motive is to describe a place that had to be left out. This place in the stories acquires 
perfect features, the image of lost paradise. Idealization is most often reflected in descriptions of beautiful landscapes, rich natural resources, successful management, especially friendly community, as well as in the conscious, and more often unconscious silence or downsizing of the negative memories about the lost place. Today, various forms of social activity have become widespread for the purpose of memorializing flooded villages: annual meetings of displaced persons, publication of books about resettled settlements, opening of memorial signs near reservoirs.

Key words: oral history, memories, migration, flooded territory, "lost paradise", idealization

\title{
Изгубљено место у сећањима на принудна пресељења \\ и у социјалним праксама
}

\author{
Ирина Коваљ-Фучило
}

\section{Резиме}

У сећањима на принудна пресељења типичан мотив представља опис места које је напуштено упркос сопственој вољи. У причањима такво место стиче идеална обележја, прерастајући у слику изгубљеног раја. Идеализација се остварује описима лепих пејзажа, природних богатстава, успешне производње, пријатељске и блиске заједнице. Истовремено, опажају се свесна или несвесна прећуткивања и тежња потискивања и ублажавања негативних сећања на изгубљено место. Данас су широко распрострањени различити облици друштвених активности везаних за меморијализацију поплављених села: годишњи састанци пресељених, издавање књига о расељеним насељима, подизање споменика.

Кључне речи: усмена историја, сећања, миграције, потопљено подручје, „изгубљени рај“, идеализација

др Ирина Коваль-Фучило

Институт искусствоведения, фольклористики и этнологии

им. М. Т. Рыльского Национальной

академии наук Украины

Примљено: 6. 3. 2020.

Е-пошта: koval-fuchylo@ukr.net

Прихваћено: 28. 5. 2020. 